\title{
US research could lose lustre
}

\section{Washington}

THE Bush Administration is planning to downgrade its four-year-old Global Climate Change research initiative at a time when there is new concern about ozone depletion in the Northern Hemisphere. The shift in focus away from global change, announced last week by presidential science adviser D. Allan Bromley, will make it harder for the $\$ 1,100$-million research effort to continue its rapid growth of the past few years.

Bromley told members of the President's Council of Advisors on Science and Technology at their monthly meeting that global change research has "matured" to the point where it should place greater emphasis on assessing the results of the research already carried out. Much of that evaluation would be done by groups outside the government, he said, such as the National Academy of Sciences.

The 1993 budget proposal submitted last month to Congress contains five presidential research initiatives-science and mathematics education, biotechnology, high performance computing and advanced materials processing, in addition to the global change effort. They represent the combined research budgets of several government agencies in a particular field, knitted together by an overall research strategy.

The initiatives on biotechnology and advanced materials are new this year. Bromley said the work involved in preparing integrated budgets for each of these initiatives makes it difficult for the government to support more than five at any one time. He said that global change is the logical one to drop because it is the oldest. The global change programme would be moved to the new category of a national research programme, according to Bromley. He said its new status "in no way is a de-emphasis" of the topic.

Robert Corell, assistant NSF director for the geological sciences and co-chair of the committee that oversees the global change effort, does not think that any change in status will hurt the programme. He said that the recent discovery in the Northern Hemisphere of atmospheric conditions that are ripe for rapid ozone depletion demonstrates that the programme is producing results that can shape federal environmental policies. "I can't imagine any agency deciding to do less than it is doing already just because global change isn't a presidential initiative," he said.

Without its status as a presidential initiative, Bromley pointed out, the global change programme would no longer qualify for "fencing" in future budget submissions. That would make it easier for the directors of the various agencies now participating in the programme, notably NASA and the National Science Foundation, to move money into different research projects. "If it's not a presidential initiative", Bromley said, "the probability of continued major increases in funding will be lower."

Bromley said the issue would be raised at a meeting on 2 March of the Federal Coordinating Committee for Science and Technology, the interagency panel that oversees all federal research. He said that the committee would review proposals for a new research initiative for the budget of the fiscal year 1994, to be submitted next January, and acknowledged that a proposal on advanced manufacturing had a great deal of support among federal science administrators.

Jeffrey Mervis

\section{Back from the dead} London

As if a phoenix from the ashes, palaeontologist V. J. Gupta has been reinstated as a member of the faculty of the Panjab University of Chandigarh, in northern India. Other members of the university expect that it is only a matter of time before he is also reinstated as head of his department. Gupta was suspended from both positions in February 1991 after repeated allegations that many of his published research papers described fossils that had not come from the sites in the Himalayas where he said he had found them, but often from other people's collections and even fossil shops in Paris.

Gupta's chief critic has been Dr John A. Talent of MacQuarie University in New South Wales (see Nature 338, 613-615; 1989), but Talent's conclusions have been corroborated by other palaeontologists outside India.

Although Gupta has consistently denied improper use of evidence, a different opinion appeared in the Journal of the Geological Society of India in January last year, based in part on a field expedition to the disputed fossil sites. Since then there have been two other India-based investigations, by the National Science Academy of India and by a field expedition last September, led by Dr A. S. Paintal.

Gupta's reinstatement last week was determined by the university's governing body, a subcommittee of the Senate known as the Syndicate, and by the vice-chancellor of the university, Professor T. $\mathbf{N}$. Kapoor. The Syndicate's decision appears to have been influenced by a 1,000-page defence against criticisms produced by Gupta as well as by the opinion of a retired judge of the High Court of India, neither of which has been made public.

John Maddox

\section{Beating swords into "critical technologies"}

\section{Chicago}

LAWRENCE Livermore National Laboratory, birthplace of "Star Wars" and a host of advanced nuclear weapons, would be turned into a billion-dollar technology development laboratory under a new plan announced last week by Representative George Brown (Democrat, California), the chairman of the House science committee. The idea, which is certain to be opposed by the Bush administration, is best seen as part of a campaign by technology supporters to foster debate within Congress about a new role for the multibillion dollar labs.

In a 8 February letter to James Watkins, secretary of the US Department of Energy (DOE), Brown argues that the United
States, in the aftermath of the Cold War, needs two technology development laboratories more than it needs three nuclear weapons laboratories. Under his proposal, all nuclear weapons work would be transferred to the Los Alamos National Laboratory, with Livermore converted into a "National Critical Technologies Laboratory". The shift, Brown says, would permit Livermore scientists to work more closely with industry and academic institutions in such areas as materials science, environmental remediation, and fusion and biotechnology. Sandia National Laboratory, the third of DOE's main weapons laboratories, would build upon its strengths in measurement and engineering by transferring civilian technologies to industry, as well as developing arms control verification and monitoring systems.

DOE's nuclear weapons budget, now almost $\$ 2,000$ million a year, would be cut 20 per cent each year for the next four years, under Brown's plan, until it reached an annual level of $\$ 750$ million by 1996 . The money saved could be spent on civilian technologies.

All three labs, seeing the post-Cold War writing on the wall, have been scrambling to diversify from weapons work to civilian and environmental technology. Livermore, for example, has shifted about half of its programmes to non-defence research.

Christopher Anderson 